\title{
Checklist of Angiosperms from the Pedra Furada Municipal Park, northeastern Brazil
}

\author{
Polyhanna Gomes $^{1 *}$, Keyla Cristina Carvalho Costa ${ }^{2}$, Maria Jesus Nogueira Rodal ${ }^{2}$ and Marccus Alves ${ }^{1}$ \\ 1 Universidade Federal de Pernambuco, Centro de Ciências Biológicas, Departamento de Botânica, Laboratório de Morfo-Taxonomia Vegetal. \\ Avenida Prof. Moraes Rego 1235, Cidade Universitária. CEP 50670-901. Recife, PE, Brasil. \\ 2 Universidade Federal Rural de Pernambuco, Departamento de Biologia, Laboratório de Fitossociologia, Área de Botânica. Rua Dom Manoel de \\ Medeiros s/n. CEP 52171-900. Recife, PE, Brasil. \\ * Corresponding author. E-mail: polyhannagomes@hotmail.com
}

\begin{abstract}
Due to the scarcity of data on the biotic diversity of rocky outcrops, this work presents the checklist of flowering plants (angiosperms) from the Pedra Furada Municipal Park ( $8^{\circ} 34^{\prime} 30^{\prime \prime}$ S, 36 $52^{\prime} 45^{\prime \prime}$ W; 3 ha), in the northeast region of Brazil. Random samples were carried out from Jan-Dec 1998 and 2004-2009, totaling 125 species and 44 families. Fabaceae (14 spp.), Euphorbiaceae (13), Convolvulaceae (10), Cyperaceae (7), Apocynaceae (6), Cactaceae (6) and Bromeliaceae (5) comprise about $50 \%$ of the species. Due to variations in the rock slope and soil depth, the plants are distributed throughout three environments: slopes (65 species), plateaus (39) and escarpments (5), with some of them occurring both in plateaus and slopes (17). Among the species of the park, some are endemic to the caatinga (e.g. Piptadenia stipulacea and Maytenus rigida), and others are restricted to rocky outcrop areas (Ameroglossum pernambucense and Pithecoseris pacourinoides), providing evidence of the park's relevance to the preservation of the local flora.
\end{abstract}

\section{INTRODUCTION}

The Brazilian semi-arid region comprises about $50 \%$ of the northeast region and is commonly associated with steppe-savanna vegetation, known as caatinga (Veloso et al. 1991). Besides the caatinga, other vegetation formations resulting from mesoclimatic and edaphic variations, such as montane and plateau forest vegetation, occur within its area (Vasconcelos-Sobrinho 1949; Andrade-Lima 1981; Ab'Saber 2003). The rocky outcrops, vegetation formations very common in the semi-arid landscape, are included among these (Velloso et al. 2002; Seabra 2005), and their dystrophic substrate significantly affects the composition and structure of the communities (Murdy et al. 1970; Phillips 1981; Gröger and Barthlott 1996; Kluge and Brufelt 2000; Szarzynski 2000). Moreover, the vegetation is subjected to different climatic conditions from the biome in which it is inserted, such as wide temperature fluctuation, low relative air humidity, high solar radiation and intense winds (Murdy et al. 1970; Phillips 1981; Gröger and Barthlott 1996; Kluge and Brufelt 2000; Szarzynski 2000).

The Pedra Furada Municipal Park is formed by a group of small and medium-size granite rock outcrops, and the Pedra Furada, which is of larger dimensions. This group presents an area of approximately 3 hectares, with an altitude between 596 and 723 meters, located approximately $200 \mathrm{~km}$ from the Atlantic coast (8³4'30" S, 36 $52^{\prime} 45^{\prime \prime} \mathrm{W}$ ), in the city of Venturosa, in the semi-arid region of the state of Pernambuco (Figures 1 and 2). The location was established as a preservation unit because it is an archaeological site with prehistoric records of the Agreste Tradition (Aguiar 1986) which, added to its scenic beauty, places it on the route for ecological tourism of the region.

Although protected, checklists are nonexistent for the park. Furthermore, while most of the studies of rock outcrop areas in the Brazilian northeast have been conducted in the semi-arid (e.g. França et al. 1997; 2005; 2006; Gomes and Alves 2009; 2010), there have been too few to understand the diversity of these environments in the region (Martinelli 2007). Basic knowledge, such as the relation with other types of caatinga vegetation, remains unclear (see Gomes and Alves 2009). To this end, the present study aimed to survey the angiosperm species

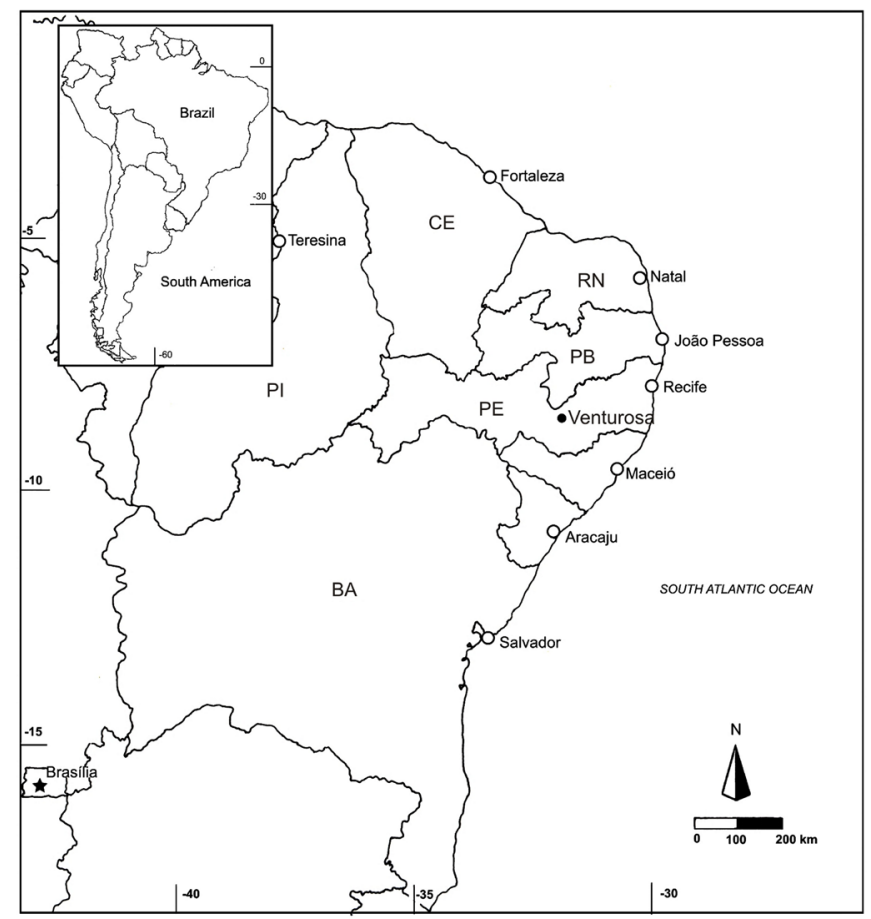

FIGURE 1. Map of the northeast region, indicating the location of the city of Venturosa, where the study area, the Pedra Furada Municipal Park, is located. 
present in the Pedra Furada Municipal Park, in order to contribute to a better phytogeographic characterization of the rocky outcrops in the Brazilian northeast.

\section{Material AND Methods}

\section{Area of study}

The Pedra Furada Municipal Park is located in the Agreste mesoregion and in the Vale do Ipanema microregion (Beltrão et al. 2005). With regards to the geomorphology, it is located in the western portion of the Borborema Plateau, one of the main landscape units of the Brazilian Northeast, formed by massifs or irregular and folded blocks, dating from the Precambrian era (MoraisNeto and Alkmin 2001; Jatobá 2003).

The climate is characterized by marked irregularity in rainfall distribution, but the conditions are milder than those found in the inter-plateau depressions (Veloso et al. 1991). The average annual precipitation is $664.7 \mathrm{~mm}$, with 6-8 dry months (0-49mm) and 4-6 rainy months (88$193 \mathrm{~mm})$, and the average annual temperature is $27^{\circ} \mathrm{C}$, with amplitude ranging from 18 to $31^{\circ} \mathrm{C}$ (ITEP 2008).

The caatinga is the predominant vegetation along the trails of the park. The other areas correspond to the rocky outcrop areas which present rupicolous vegetation, predominantly shrub and herbaceous vegetation. The largest rocky outcrop of the area, called Pedra Furada, has three types of habitats - escarpments, plateaus and slopes - which are differentiated primarily by the rock slope and soil depth. The escarpments are characterized by shallow or nonexistent soil and by marked inclination. These steep sections alternate with plateaus, where the soil is still shallow, however of a sufficient depth to support a more shrubby vegetation. On the other hand, the slopes refer to the locations at the base of the Pedra Furada, where the largest accumulation of soil occurs and the vegetation is denser and dominated by shrubby-arboreal species.
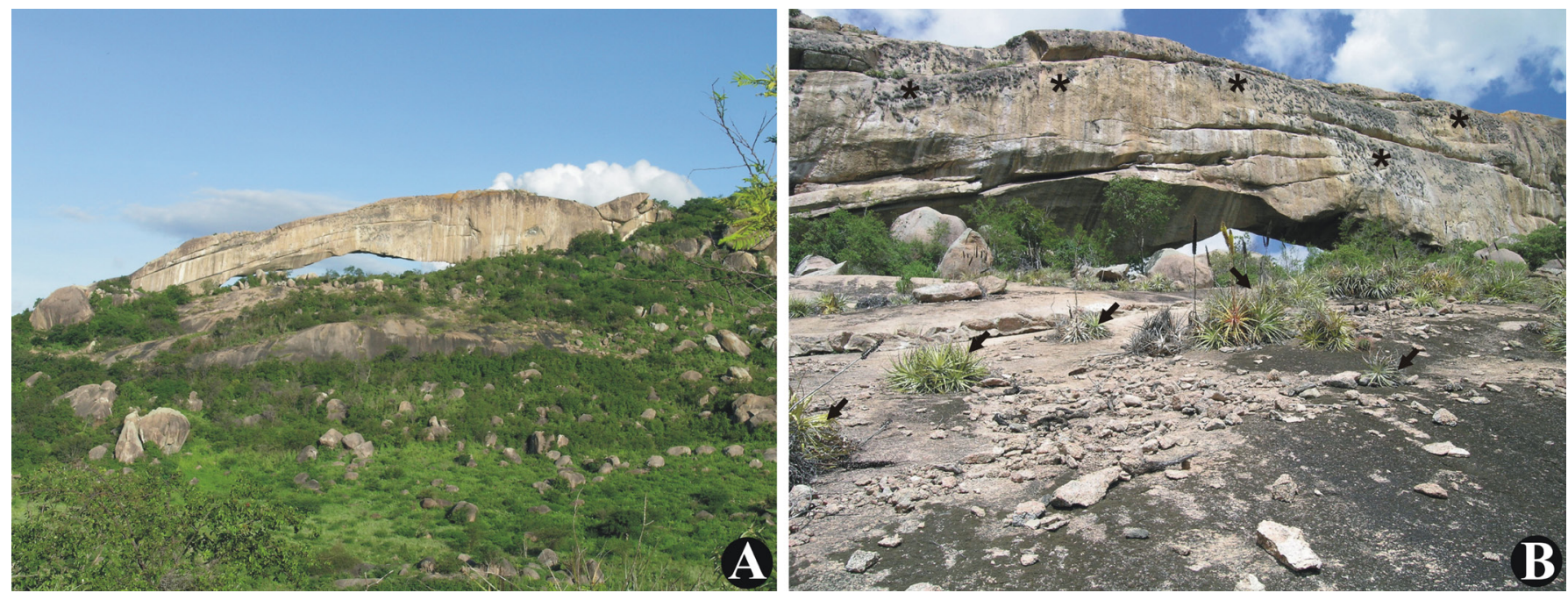

Figure 2. Overview of the Pedra Furada Municipal Park: A. some of the rocky outcrops in the study area. Pedra Furada is the largest outcrop and presents an arch-shaped top, which presents shrubby caatinga vegetation at its base; B. one of Pedra Furada's plateaus. In the foreground, Encholirium spectabile (Bromeliaceae) vegetation islands (narrows). Above and background, Tillandsia species carpets (Bromeliaceae) covering the steep sections of the rock (asterisks).

\section{Sample collections}

Monthly samples of the angiosperm flora were conducted within the period from January to December 1998, and semiannual samples were carried out from 2004 to 2009 , during the dry and rainy seasons. The collections were carried out randomly, including all the types of phyto-physiognomies occurring within the area, and were more intensive on the rocky outcrop that gives its name to the park. The material was processed according to the usual methodology in botanical studies (Mori et al. 1985) and input into the PEUFR and UFP herbaria (see Index Herbariorum at http://sweetgum.nybg.org/ih).

The species identifications were carried out by consulting the UFP, PEUFR, IPA, HUEFS, SP and SPF herbarium collections (see Index Herbariorum in http:// sweetgum.nybg.org/ih), specialized bibliography and specialists. The resulting floristic list is consistent with the APG III (2009) proposed phylogenetic classification.

\section{RESULTS AND DISCUSSION}

A total of 125 species were found, distributed in 44 families, with Fabaceae (14 species), Euphorbiaceae (13 spp.), Convolvulaceae (10 spp.), Cyperaceae (7 spp.), Apocynaceae (6 spp.), Cactaceae (6 spp.) and Bromeliaceae (5 spp.) being the richest families, comprising approximately $50 \%$ of the species (Table 1; see some species in Figure 3). Several studies have shown that Fabaceae has higher richness within rock outcrop areas in the northeast region of Brazil (França et al. 1997; Araújo et al. 2008; Porto et al. 2008; Gomes and Alves 2009), which differs from those of the southeast region (Oliveira et al. 2004; Oliveira and Godoy 2007). This is the most important taxonomic group in caatinga vegetation (Queiroz 2002) and the richest one in the present study, with species belonging to diverse genera. Piptadenia stipulacea, Senna martiana and Poincianella gardneriana, endemic to the caatinga (Giulietti et al. 2002), and Acacia bahiensis, Mimosa ophthalmocentra and Parapiptadenia zehntneri, typical species from this type of vegetation (Queiroz 2009), are generally distributed in deeper soils within the study site.

Similarly, Euphorbiaceae is common in the rocky outcrops of the region, however with predominance of the species belonging to the genus Croton (França et al. 1997; 2005; 2006; Carneiro-Torres et al. 2002; Gomes and Alves 2009; 2010), represented by Croton cf. gardnerianus, 
Croton micans and Croton heliotropiifolius. Jatropha molissima, Jatropha ribifolia and Manihot epruinosa, three other species of the family that occur in the park, are also considered endemic to the caatinga, which is also true for the species of Cactaceae Pilosocereus pachycladus ssp. pernambucoensis and Melocactus oreas (Giulietti et al. 2002; Taylor and Zappi 2002) which were also found in the park. In addition to these, another ten species from various families are also considered endemic to the caatinga: Cynophalla flexuosa, Commiphora leptophloes, Cordia leucocephala (Figure 3A), Encholirium spectabile, Herissantia tiubae, Ipomoea brasiliana, Lippia gracilis, Maytenus rigida, Sida galheirensis and Spondias tuberosa (Figure 3B) (Giulietti et al. 2002).

Although a relationship exists between the vegetation of the outcrop and the surrounding areas, the outstanding occurrence of Bromeliaceae is in accordance with the floristic composition of Brazilian rock outcrops (see Caiafa and Silva 2007; Ribeiro et al. 2007). Despite the absence of a systematic evaluation, Encholirium spectabile and Tillandsia streptocarpa visually appear to be the most abundant species within the study area in terms of vegetation structure, with $E$. spectabile very important in Northeastern Brazilian outcrops (França et al. 1997; 2005; 2006; Porto et al. 2008). Cyperaceae, one of the richest families within the area, is also typical from outcrops, however on a pantropical scale (Barthlott et al. 1993; Ibisch et al. 1995), including those from the southeast (e.g. Ribeiro et al. 2007) and northeast regions of Brazil (Porto et al. 2008; Gomes and Alves 2009). Despite the fact that Velloziaceae is equally common in rocky outcrops (e.g. Porembski et al. 1997; Oliveira et al. 2004; Oliveira and Godoy 2007), it does not present significant richness in the northeast region. At the Pedra Furada Municipal Park, it is represented by a single species, Nanuza plicata, whose population is restricted to a plateau in the middle section of Pedra Furada.

Convolvulaceae does not characterize rocky outcrops and its species are found mainly in the sections of caatinga vegetation of the park. On the other hand, Apocynaceae, the fifth richest family in this study, is one of the main taxa of the vegetation of rocky environments in South America (see Barthlott and Porembski 2000a). Its species stand out in the physiognomy of Pedra Furada, especially Ditassa hastata. Another representative species of the park, Calotropis procera, is native to Asia and occurs as an invasive species in the caatinga. It is well adapted to semiarid conditions (Fontella-Parreira 1980) and represents a risk to the native flora due to competition.

Considering the distribution of species within the three environments of Pedra Furada, the following data were registered: 65 species occurred in the slope sections, 39 in the plateaus, and 17 were registered both in the plateaus and the slopes (Table 1). Only five species colonize the escarpments within the areas of study, and four of them belong to the genus Tillandsia, which are distributed on steep sections, covering the rock as a "carpet". On the slope, where there is a higher accumulation of organic material in the soil, the vegetation is dominated by arboreal-shrub species, such as Cynophalla flexuosa, Erythrina velutina, Luetzelburgia auriculata, Spondias tuberosa, and Ziziphus joazeiro, typical of the arboreal caatinga (Andrade-Lima 1981). On the other hand, on the plateaus, individuals from different species are not distributed uniformly on the rock surface; they are grouped in vegetation islands.

Cyrtopodium intermedium, Gonolobus cearensis (Figure 3C), Matelea maritima, Nanuza plicata, Nicotiana glauca and Pithecoseris pacourinoides (Figure 3D) were found exclusively on plateaus in the medial portion of the outcrop, and Ameroglossum pernambucense (Figure 3E) and Callisthene microphyla are distributed exclusively on the top plateaus. This variation of the floristic composition with altitude has already been observed before in mountain environments in the Northeast region (Agra et al. 2004; Gomes and Alves 2009). The populations of Ditassa hastata also showed limited distribution, however in places with strong exposure to the light, being absent in the sections where the solar incidence is less intense. However, other species occur throughout the area of study, such as Cnidoscolus loefgrenii, Melochia tomentosa (Figure $3 \mathrm{~F}$ ) and Sida galheirensis, these latter two being widely distributed throughout the caatinga, especially in areas with some human interference (Amorim et al. 2009).

While most of the species mentioned above are reported from the caatinga surrounding these outcrops, there are two species (Ameroglossum pernambucense - Scrophulariaceae and Pithecoseris pacourinoides - Asteraceae, Figures 3D-E) restricted to rocky environments of the northeast. Rare and endemic species are common in rocky outcrops (Ibisch et al. 1995; Seine at al. 2000), possibly because edaphic and climatic isolation promotes speciation (Barthlott and Porembski 2000b). Rocky outcrops of the southeastern Brazilian Atlantic Forest present a higher number of endemic species, and have a flora with greater similarity to restinga when compared to the immediately surrounding forest matrix (see Meirelles et al. 1999; Porembski 2007; Ribeiro et al. 2007). In relation to outcrops inserted in the cerrado matrix, Oliveira and Godoy (2007) found several common species to the surrounding area, as observed here. Thus, the degree of shared species between rocky outcrops and the surrounding vegetation seems to be related to the environmental similarities between these two environments.

Finally, this study showed that the Pedra Furada Municipal Park presents relevance to the preservation of the local flora, taking into account the fact that its plant diversity includes both endemic species of the caatinga and species restricted to rock outcrops. We also expect that the information contained in the present study will be useful to the development of a management plan for the park. 
TABLE 1. List of the species, their respective families and voucher specimens found in the Pedra Furada Municipal Park, semi-arid region of northeastern Brazil; * species observed within the study site, but not collected due to the difficult access to their individuals; $†$ species registered in digital image database (Figure 3G).

\begin{tabular}{|c|c|c|c|}
\hline FAMILY & SPECIES & ENVIRONMENT & VOUCHER \\
\hline ACANTHACEAE & Ruellia asperula (Mart. \& Ness) Lindau & $\mathrm{P}$ & K. C. 187 \\
\hline AMARANTHACEAE & Alternanthera brasiliana (L.) Kuntze & $P$ & K. C. 37 \\
\hline \multirow{2}{*}{ ANACARDIACEAE } & Myracrodruon urundeuva Allemão & S & K. C. 154 \\
\hline & Spondias tuberosa Arruda & S & Y. M. 28 \\
\hline \multirow{6}{*}{ APOCYNACEAE } & Aspidosperma pyrifolium Mart. & $\mathrm{S}$ & K. C.180 \\
\hline & Calotropis procera (Aiton) W.T.Aiton & S & K. M. 70 \\
\hline & Ditassa glaziovii E. Fourn & $\mathrm{P}$ & K. C. 80 \\
\hline & Ditassa hastata Decne. & $P$ & P. G. 825 \\
\hline & Gonolobus cearensis Malme & $\mathrm{P}$ & P. G. 819 \\
\hline & Matelea nigra (Decae.) Morillo \& Fontella & $\mathrm{P}$ & P. G. 821 \\
\hline Araceae & Philodendron bipinnatifidum Schott ex Endl. & E & $* \dagger$ \\
\hline ARISTOLOCHIACEAE & Aristolochia sp. & S & Y. M. 26 \\
\hline \multirow{3}{*}{ ASTERACEAE } & Ageratum conyzoides L. & $\mathrm{P}$ & P. G. 398 \\
\hline & Pithecoseris pacourinoides Mart. ex DC. & $\mathrm{P}$ & P. G. 393 \\
\hline & Vernonia chalybaea Mart. ex DC. & $\mathrm{P}$ & P. G. 400 \\
\hline \multirow{2}{*}{ BignONIACEAE } & Pithecoctenium crucigerum (L.) A. Gentry & $\mathrm{S}$ & P. G. 827 \\
\hline & Tabebuia aurea (Silva Manso) Benth. \& Hook.f. ex S.Moore & S & K. C.179 \\
\hline \multirow{3}{*}{ BORAGINACEAE } & Cordia globosa (Jacq.) Kunth & S & K. C. 30 \\
\hline & Cordia leucocephala Moric. & $\mathrm{S}$ & K. C.131 \\
\hline & Cordia verbenacea DC. & $S$ & K. C. 104 \\
\hline \multirow{5}{*}{ BROMELIACEAE } & Encholirium spectabile Mart. ex Schult. \& Schult.f. & $\mathrm{P}$ & K. C. 170 \\
\hline & Tillandsia didisticha (E. Morren) Baker & $\mathrm{E}$ & P. G. 404 \\
\hline & Tillandsia loliacea Mart. ex Schult. \& Schult.f. & $\mathrm{E}$ & K. C. 106 \\
\hline & Tillandsia recurvata (L.) L. & $\mathrm{E}$ & K. C. 79 \\
\hline & Tillandsia streptocarpa Baker & E & K. C. 121 \\
\hline BURSERACEAE & Commiphora leptophloeos (Mart.) J.B. Gillett & $\mathrm{S}$ & K. С. 42 \\
\hline \multirow{6}{*}{ CACtaceae } & Cereus jamacaru DC. & P, S & K. C. 171 \\
\hline & Harrisia adscendens (Gürke) Britton \& Rose & $\mathrm{S}$ & K. C. 169 \\
\hline & Melocactus oreas Miq. & $\mathrm{P}, \mathrm{S}$ & K. С. 62 \\
\hline & Pilosocereus gounellei (F.A.C.Weber) Byles \& G.D.Rowley & $\mathrm{P}$ & K. C. 172 \\
\hline & Pilosocereus pachycladus Ritter subsp. pernambucoensis (F.Ritter) Zappi & S, P & K. C. 60 \\
\hline & Tacinga palmadora (Britton and Rose) N.P. Taylor and Stuppy & $\mathrm{S}$ & K. C. 174 \\
\hline \multirow{3}{*}{ CAPPARACEAE } & Cynophalla flexuosa (L.) J.Presl. & $\mathrm{S}$ & K. C. 12 \\
\hline & Cynophalla hastata (Jacq.) J.Presl. & $\mathrm{S}$ & K. C. 192 \\
\hline & Hemiscola diffusa (Banks ex DC.) Iltis. & $\mathrm{P}$ & P. G. 403 \\
\hline Celastraceae & Maytenus rigida Mart. & S, P & K. C. 11 \\
\hline COMmelinaceAe & Commelina obliqua Vahl & $P$ & K. C. 99 \\
\hline \multirow{10}{*}{ Convolvulaceae } & Ipomoea acuminata (Vahl) Roem. \& Schult. & S & A. R. 08 \\
\hline & Ipomoea alba $\mathrm{L}$. & $\mathrm{S}$ & A. R. 15 \\
\hline & Ipomoea brasiliana Meisn. & S & A. R. 06 \\
\hline & Ipomoea nil (L.) Roth & $\mathrm{S}$ & P. G. 385 \\
\hline & Ipomoea purpurea (L.) Roth & S & A. R. 02 \\
\hline & Ipomoea rosea Choisy & $\mathrm{S}$ & P. G. 387 \\
\hline & Ipomoea subincana Meisn. & S & A. R. 07 \\
\hline & Jacquemontia evolvuloides Meisn. & S, P & P. G. 386 \\
\hline & Merremia aegyptia (L.) Urb. & S & A. R. 04 \\
\hline & Operculina macrocarpa (L.) Urb. & S, P & A. R. 23 \\
\hline
\end{tabular}


TABLE 1. Continued.

\begin{tabular}{|c|c|c|c|}
\hline FAMILY & SPECIES & ENVIRONMENT & VOUCHER \\
\hline CUCURBItACEAE & Momordica charantia L. & $\mathrm{S}$ & K. C. 86 \\
\hline \multirow{7}{*}{ CYPERACEAE } & Bulbostylis scabra (J.Presl \& C.Presl) C.B.Clarke & $\mathrm{P}$ & P. G. 818 \\
\hline & Cyperus aggregatus (Willd.) Endl. & $\mathrm{P}$ & S. M. 102 \\
\hline & Cyperus schomburgkianus Ness & $\mathrm{P}$ & P. G. 822 \\
\hline & Cyperus uncinulatus Schrad. ex Nees & $\mathrm{P}$ & S. M. 80 \\
\hline & Lipocarpha micrantha (Vahl) G.C.Tucker & $\mathrm{P}$ & S. M. 75 \\
\hline & Pycreus capillifolius (A.Rich.) C.B.Clarke & $\mathrm{P}$ & S. M. 100 \\
\hline & Rhynchospora contracta (Nees) J.Raynal & $\mathrm{S}$ & S. M. 77 \\
\hline \multirow{2}{*}{ DIOSCOREACEAE } & Dioscorea ovata Vell. & $\mathrm{S}$ & K. C. 135 \\
\hline & Dioscorea piperifolia Humb. \& Bonpl. ex Willd. & $\mathrm{S}$ & K. C. 193 \\
\hline \multirow{13}{*}{ EUPHORBIACEAE } & Acalypha multicaulis Müll.Arg. & $\mathrm{S}$ & P. G. 402 \\
\hline & Astraea lobata (L.) Klotzsch & $\mathrm{S}, \mathrm{P}$ & K. C. 70 \\
\hline & Bernardia sidoides (Klotzsch) Müll.Arg. & $\mathrm{S}, \mathrm{P}$ & K. C. 132 \\
\hline & Cnidoscolus loefgrenii (Pax \& K.Hoffm.) Pax \& K.Hoffm. & $\mathrm{S}, \mathrm{P}$ & K. C. 88 \\
\hline & Croton cf. gardnerianus Baill. & $\mathrm{S}$ & K. C. 107 \\
\hline & Croton micans Sw. & $\mathrm{S}, \mathrm{P}$ & K. C. 109 \\
\hline & Croton heliotropiifolius Kunth & $\mathrm{S}$ & K. C. 53 \\
\hline & Euphorbia hyssopifolia L. & $\mathrm{S}$ & K. C. 128 \\
\hline & Euphorbia serpens Kunth & $\mathrm{S}$ & K. C. 130 \\
\hline & Jatropha mollissima (Pohl) Baill. & $\mathrm{S}, \mathrm{P}$ & P. G. 824 \\
\hline & Jatropha ribifolia (Pohl) Baill. & $\mathrm{S}, \mathrm{P}$ & K. C. $132 \mathrm{a}$ \\
\hline & Manihot epruinosa Pax \& K.Hoffm. & $\mathrm{S}$ & K. C. 25 \\
\hline & Tragia volubilis $\mathrm{L}$. & $\mathrm{S}$ & P. G. 399 \\
\hline \multirow{14}{*}{ FABACEAE } & Acacia bahiensis Benth & $\mathrm{S}$ & K. C. 140 \\
\hline & Anadenanthera colubrina (Vell.) Brenan & $\mathrm{S}, \mathrm{P}$ & K. C. 82 \\
\hline & Bauhinia cheilantha (Bong.) Steud. & $\mathrm{S}$ & K. C. 181 \\
\hline & Erythrina velutina Willd. & $\mathrm{S}$ & K. C. 167 \\
\hline & Indigofera suffruticosa Mill. & $\mathrm{S}$ & K. C. 221 \\
\hline & Libidibia ferrea (Mart. ex Tul.) L.P.Queiroz var. ferrea & $\mathrm{S}$ & K. C. 72 \\
\hline & Luetzelburgia auriculata (Allemão) Ducke & $\mathrm{S}$ & K. C. 185 \\
\hline & Mimosa ophthalmocentra Mart. ex Benth. & $\mathrm{S}$ & K. C. 189 \\
\hline & Mimosa cf. tenuiflora (Willd.) Poir. & $\mathrm{S}$ & K. C. 117 \\
\hline & Parapiptadenia zehntneri (Harms) M.P.M. de Lima \& H.C. de Lima & $\mathrm{S}$ & K. C. 165 \\
\hline & Parkinsonia aculeata L. & $\mathrm{S}$ & K. C. 183 \\
\hline & Piptadenia stipulacea (Benth.) Ducke & $\mathrm{S}$ & P. G. 831 \\
\hline & Poincianella gardneriana (Benth.) L.P.Queiroz & $\mathrm{S}$ & K. C. 186 \\
\hline & Senna martiana (Benth.) H.S. Irwin \& Barneby & $\mathrm{S}$ & K. C. 223 \\
\hline LAMIACEAE & Hyptis aff. fruticosa Salzm. ex Benth. & $\mathrm{S}, \mathrm{P}$ & K. C. 160 \\
\hline LOASACEAE & Aosa rupestris (Gardner) Weigend & $\mathrm{P}$ & P. G. 391 \\
\hline \multirow{4}{*}{ MALPIGHIACEAE } & Banisteriopsis sp. & $\mathrm{S}$ & K. C. 153 \\
\hline & Galphimia brasiliensis (L.) A. Juss & $\mathrm{S}$ & K. C. 101 \\
\hline & Heteropterys tricanthera A. Juss. & $\mathrm{S}$ & P. G. 830 \\
\hline & Mascagnia sp. & $\mathrm{S}$ & K. C. 02 \\
\hline \multirow{4}{*}{ MALVACEAE } & Helicteres sp. & $\mathrm{P}$ & * \\
\hline & Herissantia tiubae (K. Schum.) Brizicki & $\mathrm{S}$ & P. G. 394 \\
\hline & Melochia tomentosa L. & $\mathrm{S}$ & K. C. 78 \\
\hline & Sida galheirensis Ulbr. & $\mathrm{S}$ & K. C. 71 \\
\hline MOLLUGINACEAE & Mollugo verticillata L. & $\mathrm{P}$ & P. G. 828 \\
\hline
\end{tabular}


Table 1. Continued.

\begin{tabular}{|c|c|c|c|}
\hline FAMILY & SPECIES & ENVIRONMENT & VOUCHER \\
\hline \multirow{2}{*}{ MYRTACEAE } & Campomanesia aromatica (Aubl.) Griseb. & $\mathrm{S}$ & K. C. 111 \\
\hline & Campomanesia eugenioides var. desertorum (DC.) Landrum & $\mathrm{S}$ & BSA 640 \\
\hline NYCTAGINACEAE & Guapira laxiflora (Choisy) Lundell & $\mathrm{S}$ & K. С. 39 \\
\hline ORCHIDACEAE & Cyrtopodium intermedium Brade & $\mathrm{P}$ & K. C. 137 \\
\hline Phytolacaceae & Microtea paniculata Moq. & $\mathrm{S}$ & K. C. 133 \\
\hline Plumbaginaceae & Plumbago scandens L. & $\mathrm{S}$ & K. C. 100 \\
\hline \multirow{2}{*}{ Poaceae } & Rhynchelytrum repens (Willd.) C.E. Hubb. & $\mathrm{S}, \mathrm{P}$ & P. G. 392 \\
\hline & Tragus berteronianus Schult. & $\mathrm{S}, \mathrm{P}$ & K. C. 127 \\
\hline \multirow{2}{*}{ Portulacaceae } & Portulaca elatior Mart. ex Rorhb. & $\mathrm{P}$ & P. G. 390 \\
\hline & Portulaca cf. hirsutissima Cambess & $\mathrm{P}$ & P. G. 405 \\
\hline \multirow{2}{*}{ RHAMNACEAE } & Rhamnidium molle Reissek & $\mathrm{S}$ & K. C. 66 \\
\hline & Ziziphus joazeiro Mart. & S & Y. M. 30 \\
\hline \multirow{2}{*}{ RUBIACEAE } & Cordiera rigida (K.Schum.) Kuntze & $\mathrm{P}$ & K. C. 143 \\
\hline & Guettarda platypoda DC. & $\mathrm{P}$ & P. G. 817 \\
\hline SANTALACEAE & Phoradendron piauhyanum Trel. & $\mathrm{S}$ & K. C. 191 \\
\hline \multirow{3}{*}{ SAPINDACEAE } & Cardiospermum corindum L. & $\mathrm{P}$ & K. C. 46 \\
\hline & Cardiospermum oliveirae Ferrucci & $\mathrm{S}$ & K. C. 155 \\
\hline & Serjania glabrata Kunth & $\mathrm{S}, \mathrm{P}$ & K. C. 182 \\
\hline SCROPHULARIACEAE & Ameroglossum pernambucense Fischer, Vogel \& Lopes & $\mathrm{P}$ & P. G. 397 \\
\hline \multirow{4}{*}{ SOLANACEAE } & Nicotiana glauca Graham & $\mathrm{P}$ & P. G. 399a \\
\hline & Solanum paniculatum L. & $\mathrm{P}$ & K. C. 184 \\
\hline & Solanum thomasiifolium Sendtn. & $\mathrm{P}$ & K. C. 55 \\
\hline & Solanum sp. & $\mathrm{P}$ & K. C. 91 \\
\hline TURNERACEAE & Turnera ulmifolia $\mathrm{L}$. & $\mathrm{P}$ & K. C. 84 \\
\hline VELLOZIACEAE & Nanuza plicata (Mart.) L.B.Sm. \& Ayensu & $\mathrm{P}$ & P. G. 866 \\
\hline \multirow{2}{*}{ VERBENACEAE } & Lantana camara L. & $\mathrm{P}$ & K. C. 159 \\
\hline & Lippia gracilis Schauer & S & K. C. 69 \\
\hline \multirow{2}{*}{ Vitaceae } & Cissus decidua Lombardi & $\mathrm{P}$ & P. G. 672 \\
\hline & Cissus simsiana Schult. \& Schult. f. & $\mathrm{P}$ & K. C. 28 \\
\hline VOCHYSIACEAE & Callisthene microphylla Warm. & $\mathrm{P}$ & P. G. 401 \\
\hline
\end{tabular}



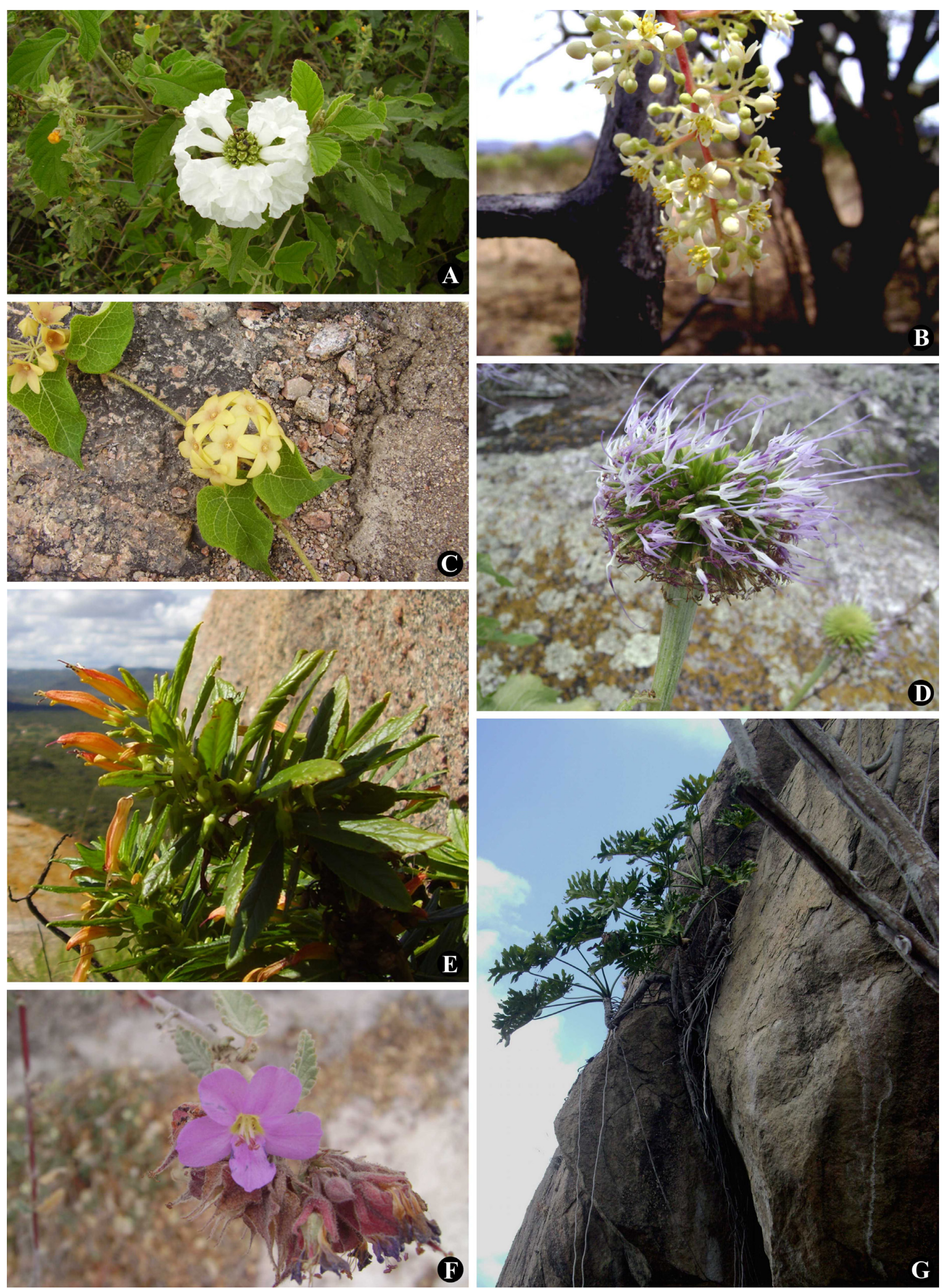

Figure 3. Some angiosperms species of the Parque Municipal Pedra Furada, NE - Brazil. A. Cordia globosa (Jacq.) Kunth (Boraginaceae); B. Spondias tuberosa Arruda (Anacardiaceae); C. Gonolobus cearensis Malme (Apocynaceae); D. Pithecoseris pacourinoides Mart. ex DC. (Asteraceae); E. Ameroglossum pernambucense Fischer, Vogel \& Lopes (Scrophulariaceae); F. Melochia tomentosa L. (Malvaceae); and G. Philodendron bipinnatifidum Schott ex Endl. (Araceae). 
ACKNOWLedgments: The authors would like to thank the Pedra Furada Municipal Park Administration; the curators of the herbaria visited; the members of the laboratories MTV (UFPE) and LAFIT (UFRPE); Dr. Ana Lúcia do Nascimento Oliveira for assistance in obtaining archaeological information; and the specialists A. Furlan (Nyctaginaceae), A. Laurêncio (Euphorbiaceae), A. Rodrigues (Convolvulaceae), A. Rapini (ApocynaceaeAsclepiadoideae), B.S. Amorim (Malvaceae), C. Jeffrey (Asteraceae and Cucurbitaceae), D. Doly (Burseraceae), E. Córdula (Fabaceae), F. França (Verbenaceae), G. Pedrali (Dioscoreaceae), J.A. Lombardi (Vitaceae), J.D. Mitchell (Anacardiaceae), J.R. Maciel (Poaceae), L. Félix (Orchidaceae), M.B. Costa e Silva (Capparaceae), M.F.A. Lucena (Euphorbiaceae), M. Nee (Solanaceae), M. Oliveira (Sapindaceae), M.T. Buril (Convolvulaceae), N. Taroda (Boraginaceae), R. Barneby (Fabaceae) and R. Barreto (Commelinaceae) for their collaboration; and Scott V. Heald for his review of the English of this manuscript.

\section{Literature Cited}

Ab'Sáber, A.N. 2003. Os domínios da Natureza no Brasil: Potencialidades Paisagísticas. São Paulo: Ateliê Editorial. 160 p.

Agra, M.F., M.R. V. Barbosa and W.D. Stevens. 2004. Levantamento Florístico Preliminar do Pico do Jabre, Paraíba, Brasil; p. 123-138 In K. Porto, J.J.P. Cabral and M. Tabarelli (ed.). Brejo de altitude em Pernambuco e Paraíba. História Natural, Ecologia e Conservação. Brasília: Ministério do Meio Ambiente.

Aguiar, A. 1986. A Tradição Agreste: estudo sobre a arte rupestre em Pernambuco. CLIO: Série Arqueológica 8: 7-98.

Amorim, B.S., J.G. Saunders, A.L. Du Bocage and M. Alves. 2009. Malvaceae; p.245-262 In M. Alves, M.F.A. Lucena, J.R. Maciel and S. Martins (ed.). Plantas de Mirandiba. Recife: APNE.

Andrade-Lima, D. 1981. The caatingas dominium. Revista Brasileira de Botânica 4(1): 149-153.

APG [=Angiosperm Phylogeny Group] II. 2009. An update of the Angiosperm Phylogeny Group classification for the orders and families of flowering plants: APG II. Botanical Journal of the Linnean Society 161: 105-121.

Araújo, F.S., R.F. Oliveira and L.W. Lima-Verde. 2008. Composição, espectro biológico e síndromes de dispersão da vegetação de um inselbergue no domínio da caatinga, Ceará. Rodriguésia 59(4): 659-671.

Barthlott, W., A. Gröger and S. Porembski. 1993. Some remarks on the vegetation of tropical inselbergs: diversity and ecological differentiation. Biogéographica 69: 105-124.

Barthlott, W. and S. Porembski. 2000a. Vascular Plants on Inselbergs: Systematic Overview; p. 103-116 In S. Porembski and W. Barthlott (ed.). Inselbergs: biotic diversity of isolated rock outcrops in tropical and temperate regions. Berlin: Ecological Studies 146.

Barthlott, W. and S. Porembski. 2000b. Why study inselbergs?; p.1-6 In S. Porembski and W. Barthlott (ed.). Inselbergs: biotic diversity of isolated rock outcrops in tropical and temperate regions. Berlin: Ecological Studies 146.

Beltrão, B.A., J.C. Mascarenhas, J.L.F. Miranda, L.C. Souza Junior, M.J.T. Galvão and S.N. Pereira. 2005. Projeto Cadastro de Fontes de Abastecimento por Água Subterrânea estado de Pernambuco: Diagnóstico do Município de Venturosa. Recife: CPRM/PRODEEM. $11 \mathrm{p}$.

Biedinger, N., S. Porembski and W. Barthlott. 2000. Vascular Plants on Inselbergs: Vegetative and Reproductive Strategies; p. 117-142 In S. Porembski and W. Barthlott (ed.). Inselbergs: biotic diversity of isolated rock outcrops in tropical and temperate regions. Berlin: Ecological Studies 146.

Caiafa, A.N. and A.F. da Silva. 2007. Structural analysis of the vegetation on a highland granitic rock outcrop in Southeast Brazil. Revista Brasileira de Botânica 30(4): 657-664.

Carneiro-Torres, D.S., F. França and I. Cordeiro. 2002. A família Euphorbiaceae na flora de inselbergs da região de Milagres, Bahia, Brasil. Boletim de Botânica da Universidade de São Paulo 20: 31-47.

Fontella-Pereira, J. 1980. Estudos em Asclepiadaceae, XI. Chave para determinação dos gêneros de Asclepiadaceae brasileiras e mais cultivadas no Brasil. Boletim do Museu Botânico Municipal de Curitiba 42: 1-16.

França, F., E. Melo and C.C. Santos. 1997. Flora de inselbergs da Região dos milagres, Bahia, Brasil: I. Caracterização da vegetação e lista de espécies de dois inselbergs. Sitientibus. Série ciências biológicas 17: 163-184.

França, F., E. Melo, A.K.A. Santos, J.G.A.N., Melo, M., Marques, M.F.B. Silva-Filho, L., Moraes and C., Machado. 2005. Estudo ecológico e florístico em ilhas de vegetação de um inselberg no semi-árido da Bahia, Brasil. Hoehnea 32(1): 93-101.

França, F., E. Melo and J. G. Miranda. 2006. Aspectos da diversidade da vegetação no topo de um inselberg no semi-árido da Bahia, Brasil. Sitientibus 6(1): 30-35.

Giulietti, A.M., R.M. Harley, L.P. Queiroz, M.R. Barbosa, A.L. Bocage and M.A. Figueiredo. 2002. Distribuição das espécies de Cactaceae na
Caatinga; p. 103-115 In E.V.S.B. Sampaio, A.M. Giulietti, J. Virgínio and C.F.L. Gamarra-Rojas (ed.). Vegetação e Flora da caatinga: Recife. Associação de Plantas do Nordeste.

Gomes, P. and M. Alves. 2009. Floristic and vegetational aspects of an inselberg in the semi-arid region of Northeast Brazil. Edinburgh Journal of Botany 66(2): 1-18.

Gomes, P. and M. Alves. 2010. Floristic diversity of two crystalline rocky outcrops in the Brazilian northeast semi-arid region. Revista Brasileira de Botânica 33(4): 661-676.

Gröger, A. and W. Barthlott. 1996. Biogeography and diversity of the inselberg (Laja) vegetation of southern Venezuela. Biodiversity Letters 3(1): 65-179.

Ibisch, P. L., G. Rauer, D. Rudolph and W. Barthlott. 1995. Floristic, biogeographical, and vegetational aspects of Pre-Cambrian rock outcrops (inselbergs) in eastern Bolivia. Flora 190: 299-314.

ITEP, 2008. ITEP - Instituto de Tecnologia de Pernambuco. Electronic Database accessible at http://www.itep.br/LAMEPE.asp. Captured on 29 August 2008.

Jatobá, L. 2003. Relevo; p. 36-44 In M.C.O. Andrade (ed.). Atlas Escolar de Pernambuco. João Pessoa: Grafset.

Kluge, M. and J. Brulfert 2000. Ecophysiology of Vascular Plants on Inselbergs; p. 143-174 In S. Porembski and W. Barthlott (ed.). Inselbergs: biotic diversity of isolated rock outcrops in tropical and temperate regions. Berlin: Ecological Studies 146.

Martinelli. G. 2007. Montane biodiversity in Brazil. Revista Brasileira de Botânica 30(4): 587-597.

Meirelles, S.T., V.R. Pivello and C.A. Joly. 1999. The vegetation of granite rock outcrops in Rio de Janeiro, Brazil, and the need for its protection. Environmental Conservation 26(1): 10-20.

Morais-Neto, J.M. and F.F. Alkmim. 2001. A deformação das coberturas Terciárias do Planalto da Borborema (PB-RN) e seu significado tectônico. Revista Brasileira de Geociências 31(1): 95-106.

Mori, S.A., L.A.M. Silva, G. Lisboa and L. Coradin. 1985. Manual de manejo do herbário fanerogâmico. Ilhéus: Centro de Pesquisas do Cacau. $97 \mathrm{p}$.

Murdy, W.H., T.M. Johnson and V.K. Wright. 1970. Competitive Replacement of Talinum mengesii by T. teretifolium in Granite Outcrop Communities of Georgia. Botanical Gazette 131(3): 186192.

Oliveira, T.D., M.C. Ribeiro, I.L.L. Costa, F.. Faria and J.E.C. Figueira. 2004. Estabelecimento de espécies vegetais em um inselberg granítico de mata atlântica. Revista Estudos de Biologia 26(57): 17-24.

Oliveira, R.B. and S.A.P. de Godoy. 2007. Composição florística dos afloramentos rochosos do Morro do Forno, Altinópolis, São Paulo. Biota Neotropica 7(2): 37-47.

Phillips, D.L. 1981. Succession in Granite Outcrop Shrub-tree Communities. American Midland Naturalist 106(2): 313-317.

Porembski, S., J. Szarzynski, J.-P. Mund and W. Barthlott. 1996. Biodiversity and vegetation of small-sized inselbergs in a West African rain Forest (Taï, Ivory Coast). Journal of Biogeography 23(1): 47-55.

Porembski, S., R. Seine and W. Barthlott. 1997. Inselberg vegetation and biodiversity of granite outcrops. Journal of the Royal Society of Western Australia 80: 193-199.

Porembski, S. 2007. Tropical inselbergs: habitat types, adaptive strategies and diversity patterns. Revista Brasileira de Botânica 30(4): 579586.

Porto, P.A. F., A. Almeida, W.J. Pessoa, D. Trovão and L.P. Felix. 2008. Composição florística de um inselbergue no agreste paraibano, município de Esperança, Nordeste do Brasil. Caatinga 21(2): 214222.

Queiroz, L.P. 2002. Distribuição das espécies de Leguminosae na Caatinga; p. 141-153 In E.V.S.B. Sampaio, A.M. Giulietti, J. Virgínio and C.F.L. Gamarra-Rojas (ed.). Vegetação e Flora da caatinga. Recife. Recife: Associação de Plantas do Nordeste.

Queiroz, L.P. 2009. Leguminosas da caatinga. Feira de Santana: Universidade Estadual de Feira de Santana. 467p.

Ribeiro, K.T., B.M.O. Medina and F.R. Scarano. 2007. Species composition and biogeographic relations of the rock outcrop flora on the high plateau of Itatiaia, SE-Brazil. Revista Brasileira de Botânica 30(4): 623-639.

Safford, H.D. and G. Martinelli. 2000. Southeast Brazil; p. 340-389 In S. Porembski and W. Barthlott (ed.). Inselbergs: biotic diversity of isolated rock outcrops in tropical and temperate regions. Berlin: Ecological Studies 146.

Sarthou, C. and J.-F. Villiers. 1998. Epilithic plant communities on inselbergs in French Guiana. Journal of Vegetation Science 9: 847860.

Seabra, G.F. 2005. A paisagem sertaneja e o lugar do turismo: as formas de relevo no Nordeste brasileiro; p. 47-57 In G.F. Seabra and J.M. Barbosa (ed.). Turismo sertanejo: Desenvolvimento Local e Integração Regional. João Pessoa: UFPB Ed. Universitária.

Seine, R., S. Porembski and U. Becker. 2000. Phytogeography; p. 435-448 
In S. Porembski and W. Barthlott (ed.). Inselbergs: biotic diversity of isolated rock outcrops in tropical and temperate regions. Berlin: Ecological Studies 146.

Szarzynski, J. 2000. Xeric Islands: Environmental Conditions on Inselbergs; p. 37-47 In S. Porembski and W. Barthlott (ed.). Inselbergs: biotic diversity of isolated rock outcrops in tropical and temperate regions. Berlin: Ecological Studies 146.

Taylor, N.P. and D. Zappi. 2002. Distribuição das espécies de Cactaceae na Caatinga; p. 123-125 In E.V.S.B. Sampaio, A.M. Giulietti, J. Virgínio and C.F.L. Gamarra-Rojas (ed.). Vegetação e Flora da caatinga. Recife. Recife: Associação de Plantas do Nordeste.

Vasconcelos-Sobrinho, J. 1949. As regiões naturais de Pernambuco, o meio e a civilização. Rio de Janeiro: Companhia Editora Americana. 441p.
Velloso, A.L., E.V.S.B. Sampaio and F.G.C. Pareyn. 2002. Ecorregiões Proposta para o bioma Caatinga. Recife: Associação de plantas do Nordeste. $76 \mathrm{p}$.

Veloso, H.P., L.C. Oliveira-Filho, A.M.S.F. Vaz, M.P.M. Lima, R. Marquete and J.E.M. Brazão, 1991. Manual técnico da vegetação brasileira. Rio de Janeiro: IBGE. 92 p.

RECEIVED: November 2009

LAST REVISED: March 2011

ACCEPTED: March 2011

Published OnLINe: April 2011

EDITORIAL RESPONSIBILITY: Frederico Augusto G. Guilherme 